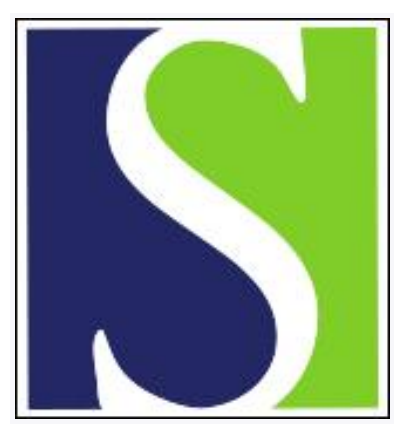

Scand J Work Environ Health 1984;10(5):321-323

https://doi.org/10.5271/sjweh.2322

Issue date: Oct 1984

Occupational solvent exposure and neuropsychiatric disorders. by Lindstrom K, Riihimaki $\mathrm{H}$, Hanninen $\mathrm{K}$

This article in PubMed: www.ncbi.nlm.nih.gov/pubmed/6523097

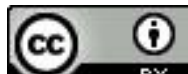




\title{
Occupational solvent exposure and neuropsychiatric disorders
}

\author{
by Kari Lindström, PhD, ${ }^{1}$ Hilkka Riihimäki, MD; ${ }^{2}$ Kari Hänninen, MSc(Eng) ${ }^{2}$
}

\begin{abstract}
LINDSTRÖM K, RIIHIMÄKI H, HÄNNINEN K. Occupational solvent exposure and neuropsychiatric disorders. Scand $J$ Work Environ Health 10 (1984) 321-323. Long-term exposure to solvents has been shown to induce neuropsychiatric disorders in workers. In this case-referent study the cases comprised 374 construction workers who had been awarded a disability pension due to a neuropsychiatric disorder in 1978-1980. Their matched referents were selected from construction workers who had been granted a pension due to other diseases in the same three-year period. The results of this study indicate that solvent exposure increases the risk of being prematurely pensioned due to neuroses, but early pensioning due to alcoholism or other neuropsychiatric disorders is not increased by solvent exposure. This same conclusion has been reached in earlier studies on this matter in other countries.
\end{abstract}

Key terms: case-referent study, disability pensions, organic solvents, painters, carpetlayers.

Several psychological studies have shown that painters and other workers with solvent exposure have disturbed psychological functions and emotional reactions $(3,4,6)$. Patients with solvent intoxication were found to have electroencephalographic abnormalities and also impairment in memory, concentration, and sensory and motor functions $(1,10)$. Persons exposed to solvents have shown, eg, changes in personality characteristics, generally in respect to affective-emotional reactions. Part of these changes are apparently secondary reactions to a lowered performance level and general health condition (5).

Swedish and Danish construction workers who have been granted a disability pension and who have been exposed to solvents have been shown to have increased morbidity due to neuropsychiatric disorders $(2,8)$. In a Danish cohort study painters had an increased risk to be pensioned due to presenile dementia (7).

The present retrospective case-referent study was undertaken to verify the results obtained in other Nordic countries and to determine the current situation in Finland.

\section{Subjects and methods}

This study was accomplished with a case-referent design. Both the cases and the referents were selected from the register of the Employment Pension Fund, which provides disability pensions to all the disabled construction workers in Finland. The subjects' age at the time the pension was granted was limited to

1 Department of Psychology, Institute of Occupational Health, Helsinki, Finland.

2 Medical Research Bureau, Employment Pension Fund, Palkkatilanportti 1, SF-00240 Helsinki, Finland.

Reprint requests to: Prof K Lindström, Institute of Occupational Health, Laajaniityntie 1, SF-01620 Vantaa, Finland.
$30-64$ years in order to exclude those without pertinent exposure. The common retirement age in Finland is 65 years.

The cases comprised all male construction workers who had been granted a disability pension because of certain neuropsychiatric disorders during the period 1978-1980. The included diagnoses were the same (with the addition of psychosomatic disorders) as those used in the investigation of Axelson et al (2). The principal psychiatric diagnoses that were excluded were primary debility, schizophrenia, and mental diseases with obvious extraneous causes, like encephalitis, traumatic disorders, etc.

The neuropsychiatric diagnosis had to be the primary medical criterion for disability, with the exception of alcoholism, which was included whenever mentioned (table 1).

The referents were selected from the construction workers who had been granted a disability pension for reasons other than neuropsychiatric disorders. They were not allowed to have any sign of neuropsychiatric disorder among the criteria listed for disability. The primary diagnoses of the referents are presented in table 2 .

The cases and the referents were matched pairwise with regard to the time of pensioning and age at that time within the range of two years. The material consisted of 374 pairs. The mean age of all the subjects at the time of pensioning was 49.1 years. That of the subjects with neurosis as the grounds for pensioning was younger ( 46.2 years).

Occupation was used as the indicator of solvent exposure. The information on occupation was obtained from the register, where it is recorded according to the mens' own responses on the pension application form. Painters and carpetlayers were classified as the exposed group, while all other occupations were considered nonexposed. 
The statistical treatment of the data was carried out with the program given by Rothman \& Boice for case-referent matched analysis (9). The MantelHaenszel chi square, the maximum likelihood estimate of the odds ratio, and its test-based confidence limits were calculated.

Table 1. The neuropsychiatric diagnoses of the cases. (ICD VIII = International Classification of Diseases, eighth revision)

\begin{tabular}{lrrr}
\hline Diagnosis (ICD VIII) & N & $\%$ \\
\hline Alcoholism (303) & 189 & 50 \\
$\quad \begin{array}{l}\text { First disability criterion } \\
\text { Second disability criterion }\end{array}$ & 105 & & \\
$\quad \begin{array}{l}\text { Third-fifth disability criterion } \\
\text { Dementia (290) }\end{array}$ & 21 & & \\
$\begin{array}{l}\text { Affective or paranoid psychosis } \\
\text { (296-297; excluding 296.10, }\end{array}$ & 12 & 3 \\
$\begin{array}{l}\text { 296.30) } \\
\text { Neurosis or persona pathologica }\end{array}$ & & \\
$\begin{array}{l}\text { (300-301) } \\
\text { Psychosomatic disease (305) }\end{array}$ & 31 & 8 \\
$\begin{array}{l}\text { Perturbationis mentis per } \\
\text { lesionem cerebri (309.20) }\end{array}$ & 103 & 27 \\
$\begin{array}{l}\text { Cerebral atrophy (347.91) } \\
\text { Vertigo or encephalopathy }\end{array}$ & 2 & 1 \\
(780.50, 781.70) & 2 & 1 \\
$\begin{array}{l}\text { Nervositas (790; excluding } \\
790.19)\end{array}$ & 18 & 5 \\
\hline Total & 15 & 4 \\
\hline
\end{tabular}

Table 2. The primary diagnoses of the referents.

\begin{tabular}{lrr}
\hline Disease & N & $\%$ \\
\hline Tumors & 33 & 8 \\
Diseases of the nervous system & 20 & 5 \\
Cardiovascular diseases & 114 & 30 \\
Respiratory diseases & 29 & 8 \\
Musculoskeletal diseases & 104 & 28 \\
Symptoms and poorly defined diseases & 37 & 10 \\
Other diseases & 37 & 10 \\
\hline Total & 374 & 100 \\
\hline
\end{tabular}

\section{Results}

Neuropsychiatric disorders were found to be associated with solvent exposure (table 3 ). Ten percent of the cases and $6 \%$ of the referents were painters or carpetlayers.

When the diagnostic subgroups of neuropsychiatric disorders were considered, a statistically significant association was discerned between neuroses and solvent exposure, whereas no such association with regard to alcoholism or other neuropsychiatric disorders was found.

Because of the small number of solvent-exposed men, scrutiny for a dose-response relationship proved to be inexpedient. However, with the use of a crude division into two exposure classes $(<16$ years and $\geq 16$ years in painting or carpetlaying), no doseresponse relationship was found.

\section{Discussion}

8 The result of this study indicates that men exposed to solvents have an increased risk of being prematurely pensioned due to neuroses, but not due to alcoholism or other neuropsychiatric disorders.

This result is in concordance with those of Swedish and the Danish case-referent studies $(2,8)$. In the Danish study neurotic disorders in particular were pronounced among individuals exposed to solvents.

Occupational health care and diagnostics of occupational diseases are quite advanced in Finland. However, work-related disorders which are mainly manifest as disturbances in affective-emotional reactions do not necessarily become diagnosed as occupational diseases. According to the data of The Finnish Register of Occupational Diseases only one painter in this material had a verified occupational disease due to solvent exposure.

In the present study the scrutiny of the etiology of the neuropsychiatric disorders was based on register data only, and therefore the data are subject to some nonspecificity and inaccuracy. The occupation reported by the pension applicants themselves was used as the indicator of solvent exposure. Obviously this

Table 3. Solvent exposure among the matched pairs of the cases and the referents. $\left(X^{2}=\right.$ McNemar chi square, NS $=$ not significant)

\begin{tabular}{|c|c|c|c|c|c|c|c|}
\hline \multirow{2}{*}{$\begin{array}{l}\text { Diagnosis } \\
\text { of cases }\end{array}$} & \multirow{2}{*}{$\begin{array}{l}\text { Exposure } \\
\text { of cases }\end{array}$} & \multicolumn{2}{|c|}{$\begin{array}{l}\text { Exposure } \\
\text { of referents }\end{array}$} & \multirow[t]{2}{*}{$\begin{array}{l}\text { Odds } \\
\text { ratio }\end{array}$} & \multirow{2}{*}{$\begin{array}{c}90 \% \\
\text { confidence } \\
\text { interval }\end{array}$} & \multirow[t]{2}{*}{$x^{2}$} & \multirow[t]{2}{*}{$p$-Value } \\
\hline & & Yes & No & & & & \\
\hline Alcoholism & $\begin{array}{l}\text { Yes } \\
\text { No }\end{array}$ & $\begin{array}{r}0 \\
16\end{array}$ & $\begin{array}{r}18 \\
155\end{array}$ & 1.1 & $0.6-2.0$ & 0.12 & NS \\
\hline Neurosis ${ }^{b}$ & $\begin{array}{l}\text { Yes } \\
\text { No }\end{array}$ & $\begin{array}{l}1 \\
2\end{array}$ & $\begin{array}{l}11 \\
94\end{array}$ & 5.5 & $1.8-16.9$ & 6.23 & $<0.05$ \\
\hline $\begin{array}{l}\text { Other neuropsychiatric } \\
\text { disease }\end{array}$ & $\begin{array}{l}\text { Yes } \\
\text { No }\end{array}$ & $\begin{array}{l}0 \\
4\end{array}$ & $\begin{array}{r}6 \\
68\end{array}$ & 1.5 & $0.5-4.3$ & 0.40 & NS \\
\hline Total & $\begin{array}{l}\text { Yes } \\
\text { No }\end{array}$ & $\begin{array}{r}1 \\
22\end{array}$ & $\begin{array}{r}35 \\
317\end{array}$ & 1.6 & $1.0-2.5$ & 2.97 & $<0.10$ \\
\hline
\end{tabular}

a Information based on occupation.

b Neurosis, persona pathologica, psychosomatic disease, nervositas. 
indicator is a good one for painters and carpetlayers, but it ignores all other workers who have been exposed to solvents during their work life. This circumstance probably weakened the associations discovered in our study.

An indicator based on occupation reveals those workers who have had a long-term and distinct exposure to solvents. Certainly also carpenters and laborers who work from time to time with painters and carpetlayers in the same workspaces become exposed to solvents. Evidently their exposure levels are in general much lower. This view was supported by a questionnaire survey undertaken among the cases and the referents to investigate the possible effects of those work-related psychosocial stress factors or neurotoxic exposures which could not be taken into account in the present study.

\section{References}

1. Arlien-Søborg A, Bruhn P, Gyldensted C, Melgaard B. Chronic painters' syndrome: Chronic toxic encephalopathy in house painters. Acta Neurol Scand 60 (1979) $149-156$.

2. Axelson O, Hane M, Hogstedt C. A case-referent study on neuropsychiatric disorders among workers exposed to solvents. Scand J Work Environ Health 2 (1976) 14-20.

3. Hane M, Axelson O, Blume J, Hogstedt C, Sundell L,
Ydreborg B. Psychological function changes among house painters. Scand J Work Environ Health 3 (1977) 91-99.

4. Lindström K. Changes in psychological performances of solvent poisoned and solvent exposed workers. Am $\mathrm{J}$ Ind Med 1 (1980) 69-84.

5. Lindström K, Martelin T. Personality and long term exposure to organic solvents. Neurobehav Toxicol 2 (1980) 89-100.

6. Lindström K, Seppäläinen AM. Raudoittaja- ja maalaritutkimus. Osa 4. Korjausmaalarien oireet, psyykkiset suoritukset, neurofysiologiset löydökset sekä liuotinaltistus. Työterveyslaitos, Helsinki 1980. (Työterveyslaitoksen tutkimuksia 170).

7. Mikkelsen S. A cohort study of disability pension and death among painters with special regard to disabling presenile dementia as an occupational disease. Scand $\mathbf{J}$ Soc Med (1980): suppl 16, 34-43.

8. Olsen J, Sabroe S. A case-referent study of neuropsychiatric disorders among workers exposed to solvents in the Danish wood and furniture industry. Scand J Soc Med (1980): suppl 16, 44-49.

9. Rothman KJ, Boice JD Jr. Epidemiologic analysis with a programmable calculator. National Institute of Health, Washington DC 1979. (NIH publication no 79-1649).

10. Seppäläinen AM, Lindström K, Martelin T. Neurophysiological and psychological picture of solvent poisoning. Am J Ind Med 1 (1980) 31-42.

Received for publication: 2 October 1984 